\title{
PREVALENCE OF INTESTINAL PARASITIC INFECTION AMONG PRIMARY SCHOOL CHILDREN IN SIRT-LIBYA
}

\author{
Hamed H. Kassem*; Sedigh A. Nass ** and Fatma A. El-Sanousi*** \\ * Faculty of Science, Benghazi University, Benghazi, Libya. \\ ** Faculty of Science, Tripoli University, Tripoli, , Libya. \\ *** Faculty of Science, Sirt University, Sirt, Libya.
}

\section{ABSTRACT}

This study was carried out to determine the prevalence of intestinal parasitic infection in primary school children in eight primary schools in Sirt city, Libya. One thousand, five hundred and forty eight feacal samples (905 males and 643 females) were examined using direct smear method and formol-ether concentration technique to determine the prevalence of intestinal parasites. Out of the number examined, 583 (37.7\%), comprising 353 (39\%) males and 230 (35.8\%) females were infected. Seven intestinal protozoan parasites were found. No helminth intestinal parasites were detected. The most common protozoan parasite was B. hominis with the highest prevalence at $17.9 \%$, followed by E. histolytica / E. dispar (14.8\%), G. lamblia (9.9\%), I. belli (4.8\%), I. butschlii (0.97\%), E. coli $(2.9 \%)$ and E. nana (2.2\%). Sex-wise prevalence showed $19.1 \%$ and $16.2 \%$ in males and females respectively. Overall prevalence of E. histolytica / E.dispar was $9.2 \%$ and $5.6 \%$ in females, while sex-wise showed $15.7 \%$ and $13.5 \%$ in males and females respectively. G. lamblia was detected in $6.3 \%$ of males and $3.6 \%$ of females, sex-wise was $10.8 \%$ for males and $8.7 \%$ for females. Significant relationship was exist between overall prevalence and sexes for B. hominis, E. histolytica / E. dispar, and G. lamblia $(P=0.000)$. Age had no effect on the prevalence of intestinal parasite $(P=0.236)$. Single infection was detected in $69.81 \%$ and $30.19 \%$ mixed infection of positive cases.

There was a significant difference between single and mixed infection $(P=0.000)$. The parasitic infection appeared to vary with the educational status of children parents. Also, associated with family size of children. The children who have body weight $(15-25$ $\mathrm{kg}$ ) showed high prevalence (17.6\%), followed by body weight (26 $35 \mathrm{~kg})(13.8 \%)$. However, low prevalence (1.5\%) at body weight> 
$46 \mathrm{~kg}$. The results revealed that the prevalence decrease with family salary income increase.

Key words: Prevalence, intestinal parasites, primary school children, Sirt, Libya.

\section{INTRODUCTION}

Intestinal parasitic infections are the major diseases of public health problems in many countries. Although many advanced studies have been done in this field. All show still million or billion of world communists are suffering from intestinal parasitic infection. Human intestinal parasites infection are widely distributed throughout the world especially in areas where poverty, low literacy rate, poor hygiene and sanitation, lack of public water supply, lower socio-economical groups ,an inadequate environment condition and over-crowding prevail.

Children are more susceptible to parasitic infections because their immune systems are not fully developed and their activities and hygiene practices put them at greater risk of infection than older age group (Fabiana and Carolina, 2002). The school environment is important as well as the home environment because children stay most of the day in the school classes, so it reflects its effect on their health (Michael et al., 1986). Few studies have been done on the prevalence of intestinal parasitic infection in Libya (Dar et al., 1979; El-Boulaqi et al., 1980; Bugharara et al., 1999 and Raof, 2002).There are still several localities in the country for which parasitic infection information is not available. In developing country like Libya, the epidemiological patterns of parasitic diseases are further complicated by the arrival of large number of migrant workers leading to destabilizing effects on the normal pattern of disease transmission.

The present study aimed to estimate prevalence and types of intestinal parasitic infections in primary schoolchildren of Sirt city, and investigate the relationships between parasitic infection and demographic, behavioral, socio-economic and environmental factors associated with the parasitic infection.

\section{MATERIALS AND METHODS}

Area of study : Sirt city is located on the Mediterranean coast . It's a far of $480 \mathrm{Km}$ east of the Libya's capital "Tripoli" (It is occupying an area of approximately $69 \mathrm{Km}^{2}$ with an average of population 140.000. Sirt has Mediterranean climate with moderate winter and hot summer, the relative 
humidity ranges from 67 to $71 \%$. The average monthly temperature during the winter ranging from 10 to $17 \mathrm{C}$, and may reach 25 to $40 \mathrm{C}$ in the summer . The average annual rainfall exceeds $253 \mathrm{~mm}$.

Collection of stool samples: A cross-sectional descriptive study was conducted among school children studying at public school in Sirt city, from June 2005 to May 2006. Eight schools (57.14\% of the total number of city primary schools) and 1548 primary school-children $(72.5 \%$ of the total number of city primary school-children) form the basis of this study.

School visits and distributed package: Each child,was given a sealed plastic bag containing a covering letter, a questionnaire, which contain the possible risk factors and a 20-ml disposable screw-capped universal container and applicator sticks. Children were asked by their class mistress to deliver the bags to their parents and was asked to provide a stool sample on the next day. At the second visit, the containers were collected .From each student, about $2 \mathrm{~g}$ of fresh stool was collected. A portion from each of the stool samples was processed with a direct microscopic technique. The remaining part of the samples were preserved in $10 \%$ formalin solution. Stool examinations were performed using the formol-ether concentration technique according to Zeibig (1997) and Markell et al. (1999). The findings were analyzed statistically using the Chi-square test.

\section{RESULTS}

Prevalence: The results showed that out of the total 1548 stool samples of primary schoolchildren , 905 stool samples of males and 643 of females . Parasitic infection was identified in 583 (353 males and 230 females) giving an overall prevalence of $37.7 \%$.The results revealed that no helminth intestinal parasites were detected, and only seven intestinal protozoan parasites were recorded. The most common protozoan parasite was $B$. hominis with the highest overall prevalence of $17.9 \%$ followed by $E$. histolytica / E. dispar $14.8 \%$, G. lamblia $9.9 \%$, I. belli $4.8 \%$, E. coli $2.9 \%$ and E. nana $2.2 \%$, whereas I. butschlii recorded of low prevalence rate, $0.97 \%$ (Table 1) .

Prevalence and sex: Infection was detected in both sexes. Out of the total positive cases, males constituted $353(39 \%)$ and females 230 (35.8\%) (Table2). B. hominis showed the highest prevalence among both sexes. Among males was $19.1 \%$ and females was $6.7 \%$ when tabulated sexwise, the percentage of prevalence was $19.1 \%$ and $16.2 \%$ for males and females, respectively. Overall prevalence between males and females showed a significant differences, the same trend was shown between overall prevalence and two sexes $(\mathrm{P}=0.000)$. E. histolytica / E. dispar was detected 
in $9.2 \%$ of males out of 1548 , whereas among females was $5.6 \%$. Sex-wise prevalence of this parasite was $15.7 \%$ (142 out 905) and $13.5 \%$, (87 out of 643) for males and females, respectively. There was a significant relationship between overall prevalence and each of males and females $(\mathrm{P}=$ $0.000)$, the same finding was noted between both sexes $(\mathrm{P}=0.000)$ as shown in Table 3.

Prevalence of single and mixed infection: The stools of $69.81 \%$ (407 out of 583) of infected children showed a single infection and $30.19 \%$ (176 out of 583) contained more than one parasite (mixed infection) in different combinations. The data revealed that there was a significant differences between single and mixed infection $(\mathrm{P}=0.000)$ as shown in Table 4.

Prevalence and age: The results revealed that the prevalence decrease with increase of age. Age had no influence on the prevalence of intestinal parasites $(\mathrm{P}=0.236)$. B. hominis showed the highest prevalence in all age groups followed by E. histolytica / E. dispar, G. lamblia and I. belli. The moderate prevalence was discernible in E. coli, E. nana. The low prevalence was detected in $I$. butschlii as shown in Table 5.

Prevalence and educated background of the parents of the children: The results revealed that the prevalence of infection was not associated with educational status of the parent's children. The parasitic infection appeared to vary with the educational status of the parents. Significant differences were exist between the overall prevalence and educated background of the parent's children $(\mathrm{P}=0.028)$ as shown in Table 6 .

Family size and infection: The results revealed that the infection with parasites associated with family size of school children. High infection rate $(41.3 \%)$ was detected among children their family size $>10$ followed by those $7-9$ family size (39.8 \%) and those $4-6$ family size $(35.3 \%)$. On the other hand, lower prevalence rate of parasitic infection was found among those children have $<4$ family size $(30.57 \%)$. No significant differences were exist between the prevalence of parasitic infection and family size of children $(\mathrm{P}=0.140)$ as shown in Table 7.

Children body weight and infection: The results showed that there was a significant relationship between the prevalence of parasitic infection and body weight $(\mathrm{P}=0.021)$ (Table 8$)$.

Socio-economic status and infection: According to the relationship between the prevalence and socio-economic status (family income per month) of children parents, the results revealed that high prevalence (40.7 $\%$ ) was detected in those children the salary income of their parents $<150$ Libyan diner / month. However, the prevalence decrease with family salary income increase, the low prevalence $(14.8 \%)$ was detected among those children whose parents have salary income > 501 diner/month (Table 9 ). 
Table 1: Prevalence $(\%)$ of intestinal parasites in primary school children from Sirt:

\begin{tabular}{|l|c|c|}
\hline \multicolumn{1}{|c|}{ Types of parasites } & $\begin{array}{c}\text { Out of total examined } \\
(\mathbf{N}=\mathbf{1 5 4 8})(\%)\end{array}$ & $\begin{array}{c}\text { Out of positive cases } \\
(\mathbf{N}=\mathbf{5 8 3})(\%)\end{array}$ \\
\hline Blastocystis hominis & $277(17.9 \%)$ & $277(47.5 \%)$ \\
\hline Entamoeba histolytica / E.dispar & $229(14.8 \%)$ & $229(39.3 \%)$ \\
\hline Giardia lamblia & $154(9.9 \%)$ & $154(26.4 \%)$ \\
\hline Isospora belli & $74(4.8 \%)$ & $74(12.7 \%)$ \\
\hline Entamoeba coli & $45(2.9 \%)$ & $45(7.7 \%)$ \\
\hline Endolimax nana & $34(2.2 \%)$ & $34(5.8 \%)$ \\
\hline Iodamoeba butschlii & $15(0.97 \%)$ & $15(2.6 \%)$ \\
\hline
\end{tabular}

Table 2. Prevalence of intestinal protozoan parasites infection among males and females children from Sirt

\begin{tabular}{|c|c|c|c|}
\hline Infections & Males (905) & Females (643) & Total \\
\hline \hline Negative & $552(61 \%)$ & $413(64.2 \%)$ & $\mathbf{9 6 5}(\mathbf{6 2 . 3 \%})$ \\
\hline \hline Positive & $353(39 \%)$ & $230(35.8 \%)$ & $\mathbf{5 8 3}(37.7 \%)$ \\
\hline \hline Total & $\mathbf{9 0 5}(\mathbf{5 8 . 5 \%})$ & $\mathbf{6 4 3}(\mathbf{4 1 . 5 \% )}$ & $\mathbf{1 5 4 8}$ \\
\hline
\end{tabular}


Table 3. Prevalence of intestinal parasites in males and females in primary school children from Sirt:

\begin{tabular}{|c|c|c|c|}
\hline \multirow[b]{2}{*}{ Types of parasites } & \multicolumn{2}{|c|}{$\operatorname{Sex}(N=1548)$} & \multirow{2}{*}{ Total } \\
\hline & Males (905) & Females(643) & \\
\hline E. histolytica / E.dispar & $142(15.70 \%)$ & $87(13.50 \%)$ & $229(14.80 \%)$ \\
\hline Entamoeba coli & $25(2.80 \%)$ & $20(3.10 \%)$ & $45(2.91 \%)$ \\
\hline Endolimax nana & $24(2.70 \%)$ & $10(1.60 \%)$ & $34(2.20 \%)$ \\
\hline Iodamoeba butschlii & $11(1.20 \%)$ & $4(0.62 \%)$ & $15(0.97 \%)$ \\
\hline Giardia lamblia & $98(10.80 \%)$ & $56(8.71 \%)$ & $154(9.95 \%)$ \\
\hline Blastocystis hominis & $173(19.11 \%)$ & $104(16.17 \%)$ & $277(17.89 \%)$ \\
\hline Isospora belli & $54(5.96 \%)$ & $20(3.11 \%)$ & $74(4.8 \%)$ \\
\hline
\end{tabular}

Table 4. Overall prevalence of single and mixed infections of intestinal parasites in primary school children in Sirt:

\begin{tabular}{|l|c|c|}
\hline Types of Infection & $\begin{array}{c}\text { Number infected } \\
\text { children }\end{array}$ & $\begin{array}{c}\text { Percentage } \\
(\boldsymbol{\%})\end{array}$ \\
\hline \hline Single Infection & 407 & $69.81 \%$ \\
\hline \hline Mixed Infection & 176 & $30.19 \%$ \\
\hline Total & $\mathbf{5 8 3}$ & $\mathbf{1 0 0 \%}$ \\
\hline
\end{tabular}

Table 5. Prevalence of intestinal parasites in different age groups of primary school children from Sirt :

\begin{tabular}{||l||c|c|c|c||c||}
\hline \multirow{2}{*}{\multicolumn{1}{|c|}{ Types of parasites }} & \multicolumn{4}{c||}{ Age groups (Years) } & \multirow{2}{*}{ Total } \\
\cline { 2 - 6 } & $\mathbf{6 - 7}$ & $\mathbf{8 - 9}$ & $\mathbf{1 0 - 1 1}$ & $>\mathbf{1 2}$ & \\
\hline \hline E. histolytica / E.dispar & 114 & 54 & 33 & 28 & $\mathbf{2 2 9}$ \\
\hline Entamoeba coli & 13 & 20 & 10 & 2 & $\mathbf{4 5}$ \\
\hline Endolimax nana & 8 & 18 & 2 & 6 & $\mathbf{3 4}$ \\
\hline Iodamoeba butschlii & 1 & 8 & 3 & 3 & $\mathbf{1 5}$ \\
\hline Giardia lamblia & 48 & 49 & 36 & 21 & $\mathbf{1 5 4}$ \\
\hline Blastocystis hominis & 86 & 106 & 40 & 45 & $\mathbf{2 7 7}$ \\
\hline Isospora belli & 15 & 20 & 12 & 27 & $\mathbf{7 4}$ \\
\hline
\end{tabular}


Table 6. Prevalence of intestinal parasitic infection according to educational background of their parents

\begin{tabular}{|l|c|c|c|}
\hline Educational of parents & $\begin{array}{c}\text { Number } \\
\text { examined }\end{array}$ & $\begin{array}{c}\text { Number } \\
\text { Infected }\end{array}$ & $\begin{array}{c}\text { Percentage } \\
\text { of infected }\end{array}$ \\
\hline Educated mother and father & 723 & 240 & $33.2 \%$ \\
\hline Non-Educated mother and father & 385 & 170 & $44.2 \%$ \\
\hline $\begin{array}{l}\text { Educated father - Non-Educated } \\
\text { mother }\end{array}$ & 399 & 157 & $39.3 \%$ \\
\hline $\begin{array}{l}\text { Educated mother - Non-Educated } \\
\text { father }\end{array}$ & 41 & 16 & $39 \%$ \\
\hline
\end{tabular}

Table 7. Prevalence of intestinal parasite according to family size of primary school children in Sirt:

\begin{tabular}{|c||c|c||c|}
\hline Family size & $\begin{array}{c}\text { Number } \\
\text { examined }\end{array}$ & $\begin{array}{c}\text { Number } \\
\text { infected }\end{array}$ & $\mathbf{( \% )}$ \\
\hline \hline $\mathbf{4}$ & 157 & 48 & $30.6 \%$ \\
\hline \hline $\mathbf{4 - 6}$ & 539 & 190 & $35.3 \%$ \\
\hline $\mathbf{7 - 9}$ & 465 & 185 & $39.8 \%$ \\
\hline$>\mathbf{1 0}$ & 387 & 160 & $41.3 \%$ \\
\hline \hline Total & $\mathbf{1 5 4 8}$ & $\mathbf{5 8 3}$ & $\mathbf{3 7 . 7 \%}$ \\
\hline
\end{tabular}

Table 8. Prevalence of intestinal parasites according to body weight of primary school children:

\begin{tabular}{|c|c|c|c|}
\hline $\begin{array}{c}\text { Body weight } \\
(\mathbf{g})\end{array}$ & $\begin{array}{c}\text { Number } \\
\text { examined }\end{array}$ & $\begin{array}{c}\text { Number } \\
\text { infected }\end{array}$ & $\begin{array}{c}\text { Percentage } \\
\text { Of infected }\end{array}$ \\
\hline $15-25$ & 651 & 272 & $41.8 \%$ \\
\hline $26-35$ & 612 & 218 & $35.6 \%$ \\
\hline $36-45$ & 204 & 70 & $34.3 \%$ \\
\hline$>46$ & 81 & 23 & $28.4 \%$ \\
\hline Total & $\mathbf{1 5 4 8}$ & $\mathbf{5 8 3}$ & $\mathbf{3 7 . 7} \%$ \\
\hline
\end{tabular}


Table (9): Prevalence of intestinal parasites according to socioeconomic status (salary income) :

\begin{tabular}{|c|c|c|c|}
\hline $\begin{array}{c}\text { Salary income } \\
\text { Libyan diner* }\end{array}$ & $\begin{array}{c}\text { Number } \\
\text { examined }\end{array}$ & $\begin{array}{c}\text { Number } \\
\text { Infected }\end{array}$ & $\begin{array}{c}\text { Percentage } \\
\text { Of infected }\end{array}$ \\
\hline$<\mathbf{1 5 0}$ & 123 & 50 & 40.7 \\
\hline $\mathbf{1 5 1}-\mathbf{3 0 0}$ & 1267 & 480 & $37.9 \%$ \\
\hline $\mathbf{3 0 1}-\mathbf{5 0 0}$ & 131 & 45 & $34.4 \%$ \\
\hline$>\mathbf{5 0 1}$ & 27 & 4 & $14.8 \%$ \\
\hline \hline Total & $\mathbf{1 5 4 8}$ & $\mathbf{5 8 3}$ & $\mathbf{3 7 . 7 \%}$ \\
\hline
\end{tabular}

Libyan diner equal to dollar*

\section{DISCUSSION}

The prevalence of parasitic infection in the present study was higher (37.7\%) compared to previous studies in Libya,12.2\% (Al-Tawaty et al., 1998), $12.88 \%$ (El-Buni and Khan, 1998) and $31.9 \%$ (Bugharara et al., 1999) and $31 \%$ (Sadaga and Kassem, 2007), and other countries, Saudi Arabia, 10.94\% (Ahmed and El Hady, 1989) and Turkey, 31.8\% (Okyay et al., 2004), West Bank- Palestine, 22.2\% (Hussein, 2011), Nigeria 25.5\% (Uhuo et al., 2011) and 34.2\% Ethiopia (Gelaw et al., 2013). In contrast, it was notably high studies conducted in Libya, 75.6\% (El- Boulaqi et al., 1980), $56.78 \%$ (Raof, 2002), 56\% (Ibrahem, 2003), Thailand, 68.1\% (Waikagul et al., 2002), Nigeria , 60\% (Enekwechi and Azubike, 1994) and Nepal, 71.2\% (Rai et al., 2004).

Only protozoan parasites were detected and no helminthic infection ,the same results was reported by Ibrahem (2003), this may due to less use of human waste as a fertilizer in agriculture and low moisture soil in Sirt area. It was reported that the use of raw sewage and wastewater for agricultural purposes leading to high risks of helminth infection in Nigeria (Akogun and Badaki, 1998) and Morocco (Habbari etal.,1999. Bastocystis hominis was the most highly encountered parasite in this study with a prevalence of 17.9 $\%$. This is consistent with previous studies (Raof, 2002, Ibrahem, 2003 and Nascimento and Moitinho, 2005). The high frequency of the protozoan infection may be due to the simple life cycles of these parasites and the simple way of transmission, especially in the presence of poor sanitary facilities , absence of clean water supply (Neva and Brown, 1994). The prevalence rate of E. histolytica / E. dispar in the present study was (14.8\%) .This is in agreement with those studies in Libya (El-Boulaqi et al., 1980), in Egypt (Hassan, 1994) and in Ethiopia (Legesse and Erko, 2004). However, this 
prevalence was relatively high as compared to the previous results among school children, $2.4 \%$ (Dar et al., 1979), $3.25 \%$ (Raof, 2002). $6.6 \%$ (Sadaga and Kassem, 2007).

The prevalence of G. lamblia was $9.9 \%$, lower than previous result in Benghazi among children as $44.4 \%$ (Dar and Friend, 1979) and $17.52 \%$ Raof, 2002) and from Riyadh, Saudi Arabia (28.57\%) (Ahmed and El-Hady (1989) ; Northern Jordan $36 \%$ (Nimri, 1993), but higher than that reported in Benghazi $6.24 \%$ (El-Buni and Khan, 1998); $5.85 \%$ (Bugharara et al., 1999). The prevalence of $I$. belli was $4.8 \%$. Previous studies reported the prevalence among children at $0.5 \%$ in Argentine (Borda et al., 1996), $0.26 \%$ in Kimberley (Meloni et al., 1993), $3.14 \%$ in Sirt city (Ibrahem, 2003) .The prevalence of E. coli $(2.9 \%)$ was relatively low when compared to previous reports Libya, 9.65\% (Raof , 2002) ; Argentine $27 \%$ (Borda et al., 1996) and Northern Thailand $25.8 \%$ (Wailkagul et al., 2002). E. nana and I. butschlli were detected at low prevalence $2.2 \%$ and $1.0 \%$ respectively, the former parasite was reported among schoolchildren at $2.5 \%$ in Northern Thailand (Wailkagul et al., 2002) and 64.3\% in Zambia (Graczyk et al., 2005) . The second was reported as $1 \%$ in Philippines (Bong-Jin et al., 2003).

The infection among males and females was $39 \%$ and $35.8 \%$, respectively. No significant differences were exist between prevalence and sex.

Which agreed the results reported by Dar et al. (1979); El-Boulaqi et al. (1980) and Raof (2002) as well as from other parts of the world (RiveroRodriguez et al., 2000; Yong et al., 2000; Quadros et al., 2004 and Champetier de Ribes et al., 2005).

The present study showed all age groups were infected. This suggests children of all ages are susceptible to parasitic infection. The minimum prevalence of parasites was discernible in old age group, this may due to the develop of immunity to infection. The absence of the difference in the prevalence between age groups was reported previously (Dar et al., 1979; Rajaá et al., 2000 and Raof, 2002 and Ijagbone and Olagunju , 2006). On the other hand similar results in age and prevalence of intestinal parasites was found statistically significant (El-Boulaqi et al., 1980 and Devera et al., 1998 and Basam and Adnan, 2005).

Infection in early ages of children has been reported by Golinska et al. (1997) and Mahfouz et al., 1997). The present study revealed that $69.81 \%$ and $30.19 \%$ of infection were single and mixed infection, respectively. Mixed infection of intestinal protozoan parasites appear to be a characteristic of parasitic infections. Single and mixed prevalence has been reported by various workers (Dar et al., 1979; Erosie et al., 2002; Dada and Erinle, 2004 and Okyay et al., 2004). Single and mixed infection were higher in males than females, this may explained that the males are more 
exposure to infection than females. The combination E. histolytical $E$. dispar with other two parasites was higher in both sexes than other parasites followed with $B$. hominis and G. lamblia, the same association was detected in other parts of the world, Saudi Arabia (Al-Fayez and Khogheer, 1989) northern Jordan (Nimri, 1993); Venezuela (Devera et al., 1997).

In the present study prevalence of infection in educated children parents was lower than those who their parents were uneducated, while those children had one educated parent showed less prevalence than those who their parents were uneducated. This finding may explained by educated parents were a ware of the precaution of infection. The influence of educational background of the parents on the infection rates was reported by Dar et al. (1979) Raof (2002) and Ibrahem (2003). Nematian et al. (2004) reported that low level of education effect on the parasitic infection.

The relation between a child's health and the mother's education is well known. Health indicators of children whose mother's education level is lower are always worse (Ozer and Aksoy, 1999). The important of parent's education and its level seems to help in decreasing the prevalence of parasitic infection and play an important role in protection of the resident. Because education of parents make them and their children aware from the sources of infection (Basam and Adnan, 2005). The present result revealed that the infection with parasites associated with family size of school children $(\mathrm{P}=0.140)$. Previous studies revealed that the infection increase with the family size increased and bed rooms in a house decreased (ChacinBonilla et al.,1993; Rajeswari et al., 1994; Solorzano-Santo et al., 2000; Basam and Adnan, 2005 and Sadaga and Kassem, 2007).

The present study revealed that high infection $(40.7 \%)$ in children from low socio-economic status than those from high socio-economic status, this agreed with observation reported by (Rajeswari et al., 1994; Yassin et al., 1999; Ibrahem, 2003 and Sadaga and Kassem, 2007). Zakai (2004) reported that increased family income has no significant role in the health status of children. Poor socio-economic of families appear to powerful determinate of infection (Nematian et al., 2004).

\section{REFERENCES:}

Ahmed, M. M. and El-Hady, H. M. (1989): A preliminary survey of parasitic infections and nutritional status among schoolchildren in Riyadh, Saudi Arabia. Journal of the Egyptian Society of Parasitology, 19: 101 - 105. 
Akogun, O.B. and Badaki, J. (1998): Intestinal helminth infection in two communities along the Benue river valley Adamawa state. The Nigerian Journal of Parasitology, 19: 67-72.

Al-Fayez, S. F. and Khogheer, Y. A. (1989). Prevalence of parasitic infections among patients attending king Abdulaziz University Hospital, Jeddah. Saudi Medical Journal, 10: 193-197.

Al-Tawaty, A. I. A.; Khan, A. H. ; El-Sharkasi, N. I. and El-Buni, A. A. (1998). Screening of Cryptosporidium oocysts in clinically immunocompetent children. The Fourth Jamahiriya Congress on Medical Sciences , Benghazi , 1-4 November 1998, pp. 242.

Basam, A. and Adnan, A. (2005). Distribution of Strongyloides stercoralis and other intestinal parasites in household in Beit-lahim city, Gaza Strip, Palestine. Annals of Alquds Medicine, 1: 48 - 52.

Bong-Jin, K. I. M.; Mee-Sun, O. C. K.; Dong-II, C. H. U. N. G.; Tai-Soon, Y. O. N. G. and Kyu-Jae, L. E. E. (2003). The intestinal parasite infection status of inhabitants in the Roxas city, the Philippines. The Korean Journal of Parasitology, 41 (2): 113 - 115.

Borda, C. E. ; Rea, M. J.; Rosa, J. R. and Maidana , C. (1996). Intestinal parasitism in San Cayetano, Corrientes, Argentina. Bullitin Pan America Health Organization, 30 (3): 227 - 233.

Bugharara, S. L.; Ali, M. Y.; Khan, A. H.; El-Sharkasi, N. and El-Refi, H. (1999). Incidence of Cryptosporidium in-patients with diarrhea . Rivista di Parasitologica, Vol. XVI (LX) - N. 2: 169-172.

Chacin-Bonilla, L., De Young , M.M., Cano, G., Guanipa , N., Estevez, J. and Bonilla , E. (1993). Cryptospridium infections in a suburban community in Maracaibo, Venezuela. American Journal of Tropical Medicine and Hyhiene, 49:63-67.

Champetier deRibes, G.; Fline, M.; Desormeaux, A. M.; Eyma, E.Montagut, P.; Champagne, C.; Pierre, J.; Pape, W. and Raccurt,C.P. (2005). Intestinal helminthiasis in school children in Haiti. Bull Soc Pathol. Exot., 98 (2): 127 - 132.

Dada, E. O. and Erinle, B. A. (2004). Study of human gastro-intestinal parasites among primary school children in Ibule Soro community of Ifedore Local Government area of Ondo state, Nigeria, Journal of Medical Laboratory Science, 13 (1) : 62 - 65 .

Dar, F. K.; El Khouly, S. I.; El-Boulaqi, H. A.; Munir, R. and ElMaghrebi, S. (1979). Intestinal parasites in Benghazi school children. Garyounis Medical Journal, 2: 3 - 7.

Dar, F. K. and Friend , J. E. (1979). Parasitoses in a closed communitya pilot study . Garyounis Medicine Journal, 2 : 95 - 96. 
Devera, R. A.; Punos, G. N.; Velasquez, V. J. ; Catanese, J. A. and Meneses, R. G. (1997). Prevalence of Blastocystis hominis in school children from Bolivar City, Venezuela. Boletin Chileno de Parasitologia, 52: 77 - 91 .

Devera, R.A.; Velasquez, V. J. and Vasquez, M. J. (1998). Blastocystosis in pre-school children from Bolivar city, Venezuela. Cadernos de Saude Publica, 14: 401 - 407.

EL-Boulaqi, H. A.; Dar, F. K. and Medini, M. S. (1980). Prevalence intestinal parasites in primary school children in Benghazi city. Journal of the Egyptian Society of Parasitology, 10 (1): 77 - 82.

El-Buni ,A.A. and Khan , A.H. (1998). Intestinal protozoan infections in Benghazi. Sebha medical Journal, 1: $106-108$.

Enekwechi, L.C. and Azubike, C.N. (1994). Survey of the prevalence of intestinal parasites in children of primary school age. West Africa Journal of medicine, 13 (4): 227 - 230.

Erosie, L.; Merid, Y.; Ashiko, A.; Ayine, M.; Balihu, A.; Muzeyin, S. J. and Teklemariam, S.; Sorsa, S. (2002). Prevalence of hookworm infection and hemoglobin status among rural elementary schoolchildren in Southern Ethiopia, Ethiop. Journal Health Development, 16 (1): 113 - 115.

Fabiana, I. and Carolina, M. (2002). Giardiasis in children. BMC Public Health, 2 (2): 5 - 11.

Gelaw, A. ; Anagaw, B.; Nigussie, B.; Silesh, B .; Yirga, A.; Alem, M.; Endris, M. and Gelaw, B. ( 2013): Prevalence of intestinal parasitic infections and risk factors among schoolchildren at the University of Gondar Community School, Northwest Ethiopia: a cross-sectional study, Tropical Medicine and International Health,16(2): 240-244.

Golinska, Z.; Lach, J.; Bany, J. and Chas, J. (1997). Intestinal parasites in for Warsaw Kindergarden children in 1994-1996. Przeglad Epidemiologiezny, 51: $411-416$.

Graczyk, T. K.; Shiff ,C. K.; Tamang, L.; Munsaka, F.; Beitin, A. M. and Moss, W. J. (2005). The association of Blastocystis hominis and Endolimax nana with diarrhea stools in Zambian school-age children. Parasitology Research, tgraczyk jhsph .edu.

Habbari, H.; Tifnouti, A.; Bitton, G. and Mandil, A. (1999): Helminthic infections associated with the use of raw wastewater for agricultural purposus in Beni Mellal, Morocco, Eastern Mediterranean Health. Journal, 5: 912-921.

Hassan , S.I. (1994). Parasitic infections in primary and secondary school in Giza Governorate, Egypt. Journal of the Egyptian Society of Parasitology, 24 (3): $597-601$. 
Hussein, A. S. (2011): Prevalence of intestinal parasites among school children in northern districts of West Bank- Palestine Advances in Applied Science Research, 2 (5):257-262.

Ibrahem, H. A. (2003). Intestinal parasitic infection among the children and neonatus admitted in Ibn-Sina Hospital, Sirt, Libya M. Sc. Thesis, Faculty of Science, Al-Tahadi University.

Ijagbone, I. F. and Olagunju, T. F. (2006). Short Communication Intestinal Helminth Parasites in School children in Iragbiji, Boripe Local Government, Osun State, Nigeria. African Journal of Biomedical Research, 9 (1): $63-66$.

Legesse, M. and Erko, B. (2004). Prevalence of intestinal parasites among schoolchildren in a rural area close to the southeast of Lake Langano , Ethiopia. Ethiopian Journal of Development, 18 (2): 116 - 120 .

Mahfouz, A. A.; EL-Morshedy, H. and Farghaly, A. (1997). Ecological determinants of intestinal parasitic infections among pre-school children in an urban squatter settlement of Egypt. Journal of Tropical Pediatrics, 43:341 - 344 .

Markell , E.K.; John , D.T. and Krotoski , W.A. (1999). Markell and Vog's Medical Parasitology. $8^{\text {th }}$ edition. W.B. Saunders Company, Philadelphia.

Meloni, B. P.; Thompson, R. C.; Hopkins, R. M.; Reynoldson, J. A. and Gracey, M. (1993). Prevalence of Giardia and other intestinal parasites in children, dogs and cats from aboriginal communities in the Kimberley. Australia Medical Journal, 158 (3): 157 - 159.

Michael, L.; Kotkat, A.; Soliman, N. K. and El-Daly, S. (1986). Role of school environmental in transmission of parasitic infections in a desert district, King Mariute ,Alexandria. Journal of the Egyptian Society of Parasitology, 16 (2) : 487 - 494.

Nascimento, S. A. and Moitinho Mda, L. (2005). Blastocystis hominis and other intestinal parasites in a community of Pitanga city, Parana state, Brazil. Rev Inst Med Trop Sao Paulo, 47 (4): 213 - 217.

Nematian, J.; Nematian, E.; Gholamrezanezhad, A. and Asgari, A.A. (2004). Prevalence of intestinal parasitic infections and their relation with socio-economic factors and hygienic habits in Tehran primary school students. Acta Tropical, 92 (3): 179 - 186.

Neva, F. A. and Brown, H. W. (1994). Basic clinical parasitology . APPIETON \& LAVGPE . Norwalk, Connecticut., U.S.A .

Nimri, L.F. (1993). Evidence of an epidemic of Blastocystis homini infections in preschool children in Northern Jordan. Journal of Clinical Microbiology, 31: 2706 - 2708. 
Okyay, P. ; Ertug, S.; Gultekin, B.; Onen, O. and Beser, E. (2004). Intestinal parasites prevalence and related factors in school children, a Western city sample-Turkey. BMC Public Health, 4: $64-71$.

Ozer , S. and Aksoy , G. (1999). Interrelationship between intestinal parasite disease in the GAP region and certain environmental factors and a prediction of health care after GAP . Acta parasitological Turcica, 23 (4) : 381-384

Quadros, R. M.; Marques, S.; Arruda, A . A.; Delfes, P. S. and Medeiros, I. A. (2004). Intestinal parasites in nursery schools of Lages, southern Brazil. Revista da Sociedade Brasileira de Medicina Tropical, 37 (5) : $422-423$.

Rajeswari, B.; Sinniah, B. and Hussein, H. (1994). Socio-economic factors associated with intestinal parasites among children living in Gombak, Malaysia , Asian Journal Publication Health ,7(1) : 21-25.

Rai, S. K.; Hirai, K.; Abe, A.; Nakanish, M.; Rai, G.; Uga , S. and Shrestha ,H. G. (2004). Study on enteric parasitosis and nutritional status of school children in remote hilly areas in Nepal. Nepal Medical College Journal, 6 (1): 1 - 6.

Rajaá, Y. A.; Assiragi, H. M.; Abuluhom, A. A.; Mohammed, A. B.; Albahr, M. H.; Ashaddadi, M. A. and Al-Muflihi, A. N. (2000). Schistosomes infection rate in relation to environmental factors in schoolchildren . Saudi Medical Journal, 21 (7): 635-638.

Raof, S. A. (2002). Intestinal Archezoa and protozoa of primary schoolchildren from Benghazi: An investigation relating to the effect of sociodemographic and environmental variables on parasitic infection . MSc . Thesis, Faculty of Science, Garyounis University .

Rivero-Rodriguez, Z.; Chourio-Lozano, G.; Diaz, I.; Cheng, R. and Rucson, G. (2000). Intestinal parasites in school children at a public institution in Maracaibo municipality, Venezuela. Investigacion Clinica, 41: 37-57.

Sadaga , G.A. and Kassem, H. H. (2007). Prevalence of intestinal parasites among primary schoolchildren in Derna district, Libya. Journal of Egyptian Society of Parasitology, 37(1): 205 - 214.

Solorzano-Santos, F.; Penagos-Paniagua, M.; Meneses-Esquivel, R.; Miranda-Novales, M.G.; Leanos-Miranda, B.; Angulo-Gonzalez, D. and Fajardo-Gutierrez, A. (2000). Cryptosporidium parvum infection in malnourished and non-malnourished children without sdiarrhea in a Mexican rural population. Revista de Investigacion Clinica, 52: $625-631$. 
Uhuo, A. C.; Odikamnoro, O. O. and Ani, O. C. ( 2011 ):The incidence of intestinal nematodes in primary school children in Ezza North Local Government Area, Ebonyi State Nigeria. Advances in Applied Science Research, 2 (5) :257-262.

Waikagul, J.; Krudsood, S.; Radomyos, P.; Radomyos, B.; Chalemrut, K.; Jonsukuntigul, P.; Kojima, S.; looareesuwan, S. and Thaineau, W. (2002). A cross-sectional study of intestinal parasitic infections among schoolchildren in Nan province, Northern, Thailand. Southeast Asian Journal of Tropical Medicine and public Health, 33 (2): 218 223.

Yong, T.S.; Sim, S.; Lee, J.; Ohrr, H.; Kim, M. H. and Kim, H. (2000). A small-scale survey on the status of intestinal parasite infections in rural villages in Nepal .Korean Journal of Parasitology, 38 : 275-277.

Zakai, H. A. (2004). Intestinal parasitic infections among primary school children in Jeddah , Saudi Arabia. Journal of the Egyptian Society of Parasitology, 34 (3) : 783 - 790 .

Zeibig, E. A. (1997). Clinical parasitology . A parasitic approach. $1^{\text {st }}$ edition. W.B. Saunders Company, Philadelphia. pp 50- 75.

\section{معدل انتشار الأصابة بالطفيليات المعوية فى أطفال المدارس الأبتدائيه

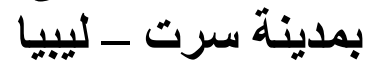

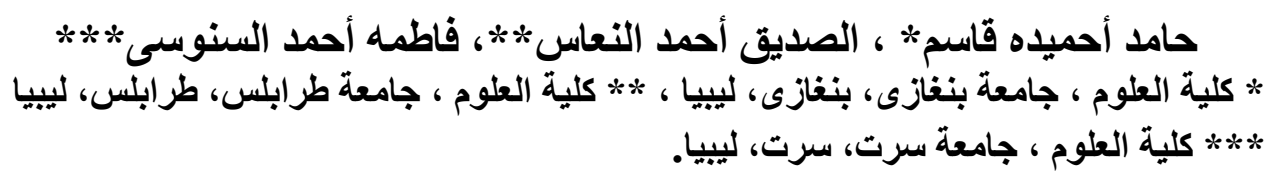

الدراسة تستهدف تحديد مدى انتشار الطفيليات المعوية بين تلاميذ ثمانية مدارس

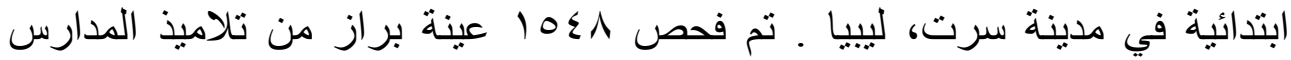

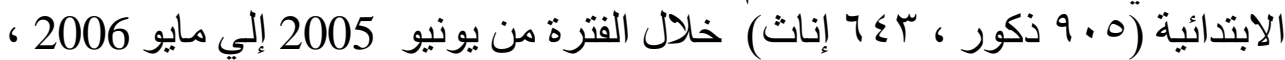
لتحديد معدل انتشار الطفيليات المعوية بين هؤلاء التلاميذ.اعتمدت الطرق التهات المستخدمة

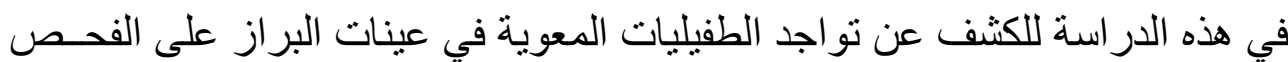

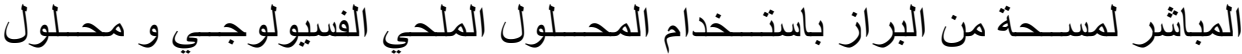

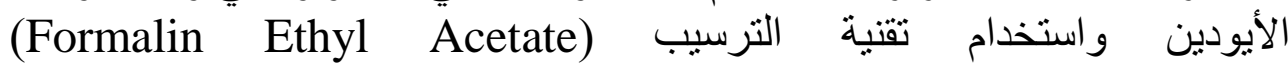


Sedimentation

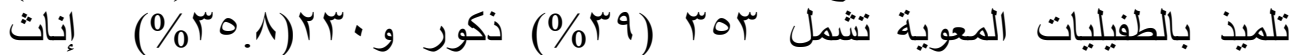

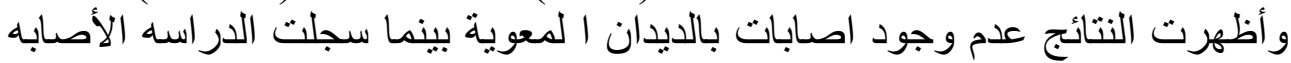

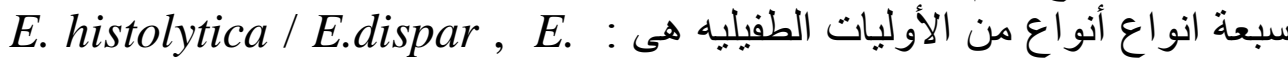
.coli , G. lamblia , B. hominis , E. nana , I. butshlli , I. belli

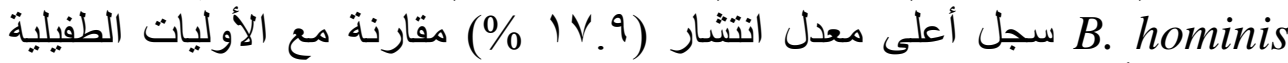

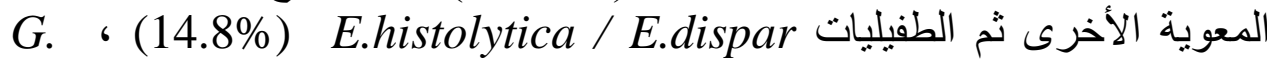
ґ.r) E. nana ، (\% r.१) E. coli ، (\% ะ.^) belli، (\% १.१)lamblia . (\%•.9v) I. butschlii و $(\%$

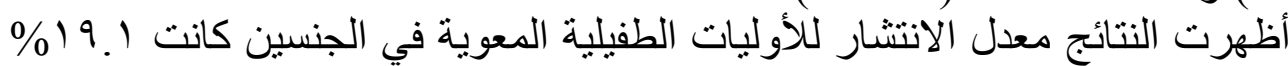

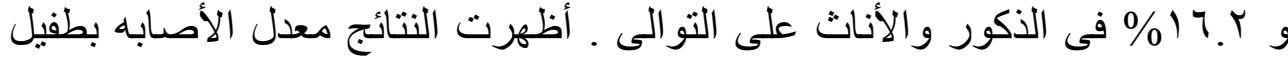

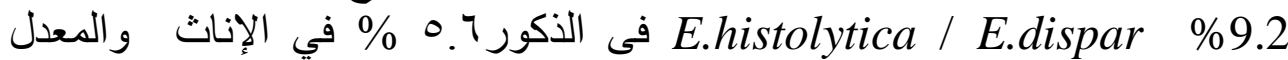

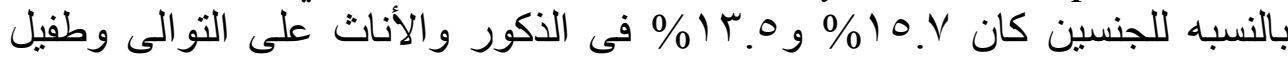
G. lamblia

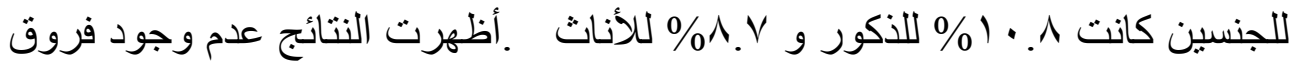
معنوية في نسبة إنتشار الأوليات الطفيلية المعوية بين المجموعات الطات العات العمرية المختلفة

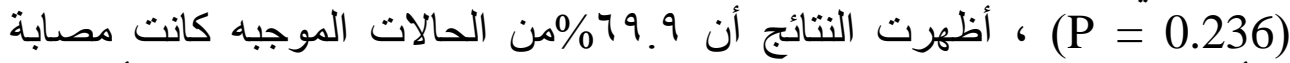

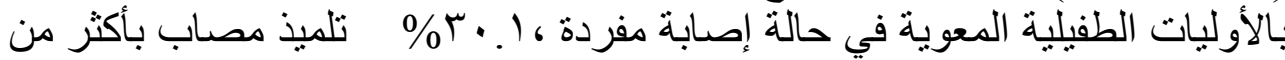

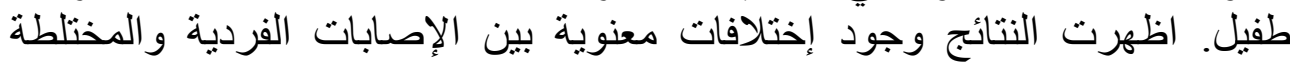
. $(\mathrm{P}=0.00)$

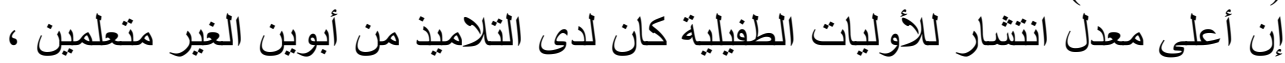

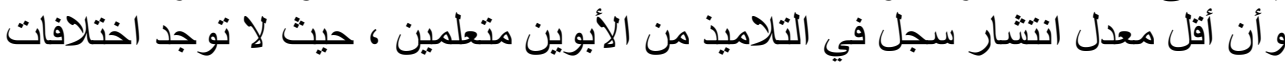

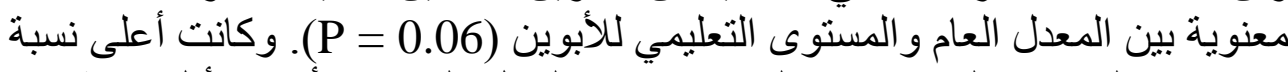

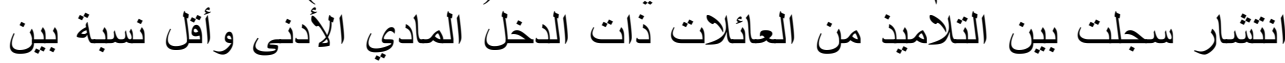

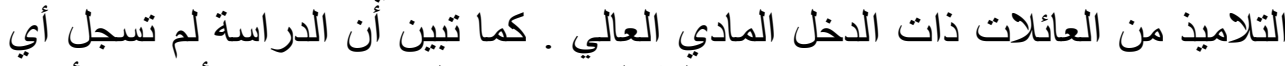

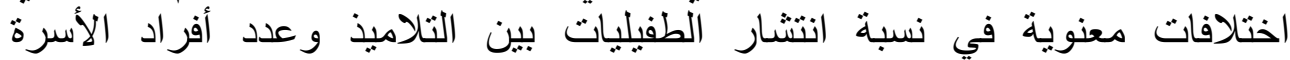

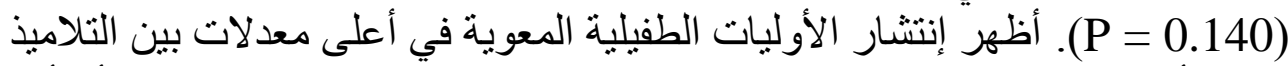

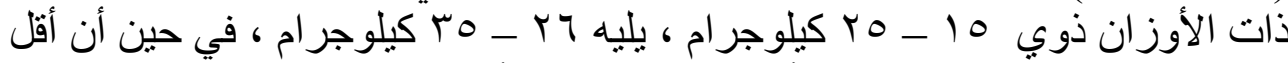

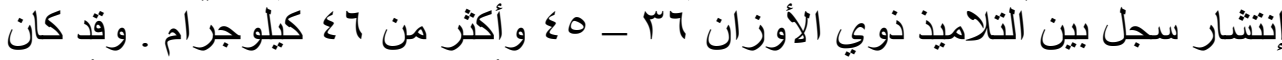

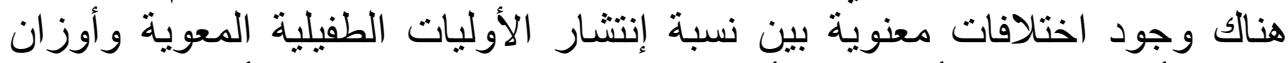

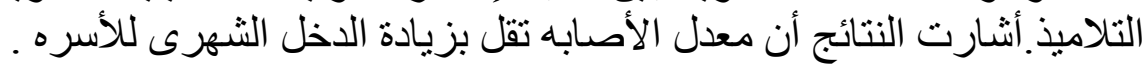

